\title{
Group Pluralism versus Group Accommodation
}

\section{A Commentary on Jean Cohen}

\author{
Avigail Eisenberg
}

In this insightful analysis of perhaps the most important legal cases to be decided by the US Supreme Court in the last decade, Jean Cohen points to one especially disturbing trend in how religious freedom is interpreted today which is indicated by the uptake by the Court of a 'real entity' or 'group personality' approach to addressing disputes involving religious organizations. Cohen focuses on two decisions - Hosanna-Tabor and Hobby Lobby - which together have shifted the interpretation of religious freedom from one informed by liberal principles that focus on protecting individual conscience and belief, to one based on what she calls a 'political theological conception of the corporate' that shields the jurisdictional authority of churches and religiously-run corporate entities from otherwise valid and reasonable laws. As Cohen shows, these decisions have established dangerous precedent and are supported by a growing legal scholarship that also resurrects ideals about the ethical independence of religious groups from the state. Her compelling analysis points out several reasons to conclude that these decisions are mistaken. To apply the notion of corporate personality so that it extends the right of religious freedom to for-profit groups and permits them to violate the rights of employees to health care benefits and employment equality is not only bad public policy, it is also jurisprudentially defective.

For Cohen, the Supreme Court's rulings rest on a convoluted and mistaken interpretation of the First Amendment of the American Constitution while indicating something more threatening as well. The cases indicate a shift to a problematic 'accommodation-ist' understanding of what freedom of religion requires in the United States that parallels a global revival of jurisdictional pluralism which travels 'under the 'freedom of religion' slogan' and is carried by 'accommodation discourse'. ${ }^{1}$ On Cohen's view, jurisdictional accommodation 'poses challenges to civil democratic states everywhere' by releasing religious groups from the responsibility of respecting the fundamental rights of individuals within their ambit. ${ }^{2}$ In this way, these decisions, and the American scholarship that supports them, threaten basic principles of liberal justice and democratic constitutionalism, individual equality, and even the sovereignty of the democratic state. In other words, the fallout from this jurisprudence is dramatic and raises serious concerns about how religious freedom is interpreted in western democracies today.

1 Jean Cohen, 'Freedom of Religion Inc.: Whose Sovereignty?' Netherlands Journal of Legal Philosophy 44(3) (2015): 171. 
I share some of Cohen's concerns about these decisions. But I think the cases point to two different approaches taken to religious freedom today, one of which can be described as group pluralism and the other as group accommodation. Group pluralism is similar to what Cohen calls 'jurisdictional accommodation' in so far as it prescribes a limited role for the state in relation to religious groups within the state. Its presence and influence might be indicated by courts relinquishing state sovereignty to corporate bodies in the manner Cohen emphasizes in her analysis. By contrast, group accommodation can permit an expansive role for the state in addressing controversies involving religious groups. Under group accommodation, courts not only weigh the interests of the state against those of religious groups but sometimes investigate and interrogate the religious practices and rules that claimants hold as integral to their faith or religious identity. Under group accommodation, the risk is that the state can overextend its appropriate authority and become the arbiter of religious practices. By contrast, this state role is precisely what group pluralism rejects when it cedes authority to religious groups. So each approach comes with a different challenge. The challenge for group pluralists, insofar as they aspire to offer a credible approach, is to carve out a meaningful role for the church without forsaking the state either as a fair regulator of associations or as an association in its own right. The challenge for group accommodationists is to guide courts (and thereby states) to make decisions about the inclusion of religious groups in the public sphere without overstepping their role by interfering in religious dogma or shaping the content and meaning of religious and cultural practices for believers.

Here, my primary focus is on Cohen's claim that religiously-inspired group-based pluralism constitutes a form of religious accommodation and further that accommodation and group pluralism threaten liberal democratic values. I agree that both Hobby Lobby and Hosanna-Tabor are disturbing cases. But more can be gained by sharply distinguishing between two different approaches to religious freedom reflected in these cases than by insisting on their similarities. Illuminating the differences between religious group-based pluralism and religious accommodation provides a clearer understanding of the different challenges characteristic of each approach and how they sometimes pull interpretations of religious freedom in different directions.

\section{Group pluralism and state citizenship}

According to Cohen's account, Hosanna-Tabor and Hobby Lobby have revived debates about 'real entity theory' or 'corporate group personality' which go back to the legal battles between church and state in the Fifteenth Century and, more recently, refer to pluralist debates in the early Twentieth Century about whether state sovereignty is final and indivisible. Whereas Cohen recognizes that most twentieth century pluralist theory was democratically inspired, she also argues that some pluralist ideas about group sovereignty threaten liberal democratic values. So it is worth briefly recounting how pluralists attempted to reconcile plural 
group sovereignty with democratic values before examining why the application of their approach in the cases Cohen assesses fails in this respect.

The aim of the early pluralists was to challenge the idea of state sovereignty as final and absolute, and some of them did so by arguing that democracy and freedom were threatened by a state that commanded all sovereign authority. British pluralists, such as Harold Laski, GDH Cole, and JN Figgis, argued that the allpowerful state is a fiction, as is the liberal 'atomistic' view of individuals. Because individuals alone are powerless against the state, they join together in groups in order to contest state power. Laski called individuals 'bundles of hyphens' ${ }^{3}$ whose ties to many and different kinds of groups give rise to fragmented and limited forms of group-based power so that no group can command complete power over all others because none commands the complete loyalty of all individuals. As a result, sovereignty is always divided and plural, and, according to Laski, legal approaches that ignore the legitimate authority of groups to which individuals are tied are both mistaken and unjust.

In making a similar argument about group sovereignty, Figgis argued that groups have 'real personality' and that states act unjustly when they deny groups - and here, the Church was central to Figgis' thinking - legal status or fail to recognize their ecclesiastical authority. ${ }^{4}$ According to Figgis, groups are organic entities with real personalities of their own rather than 'mere creatures of the sovereign'. That said, Figgis recognized limits to group power and, in particular, to Church authority. For instance, he pointed out to Christians of his day that they are citizens of a state that is religiously diverse, which limits the power of the Church over them as citizens, and distinguishes the circumstances of their day from those of religiously uniform communities of medieval times. ${ }^{6}$ In these respects, Figgis recognized the legitimacy, importance, and separateness of a political and civil sphere. ${ }^{7}$

3 Harold J. Laski, The Foundations of Sovereignty and Other Essays (New York: Harcourt, Brace and Co., 1921), 170.

4 J. Neville Figgis, Churches in the Modern State (London: Longmans, Green and Co., 1913), 42.

5 Ibid., 8

6 Also, 'The cardinal fact which faces us today is the religious heterogeneity of the modern State' (Ibid., 113).

7 Ibid., 103. Figgis is often viewed to be amongst the most groupist of contemporary pluralists, yet his position on the Church's jurisdictional authority seems more modest than that of the US Court in Hobby Lobby: '...we neither claim to be outside the law nor to exercise control over politics. For the whole question is prejudiced by recollections of the Middle Ages and the seventeenth century...[when the church] ...identified citizenship with Churchmanship, and she claimed to dictate on religious grounds the law and policy of the State. Much of the prejudice against just claims of religious bodies arises from the recollection of these facts, and the evils of clerical immunities' (Ibid., 105-106). At the same time, it would be a mistake to conclude that Figgis championed a strong state. At most, he recognized the importance of the civic realm and thereby established a basis for later pluralists to build a more robust conception of the state as an association of citizenship. 
Despite the methodological holism and ecclesiastical sympathies of Figgis' pluralism, even he acknowledged a role for the state in governing and regulating issues important to citizenship. Without such a role, pluralism was incoherent and dissolved, as critics claimed of Laski's pluralism, into anarchism ${ }^{8}$ or, as Figgis accused his co-religionists, into neo-medievalism. Yet, what was missing from all the pluralist theories was a developed account of how the state works as an association of citizens. Early pluralists were mostly silent about citizenship in a pluralistic state. Whereas they did not conceive pluralism as ceding carte blanche authority to religious or any other groups, they also showed little interest in explaining how citizens retained their rights in the face of groups that exercised power over them.

One way to read Hobby Lobby is as a case that reflects this deficiency in the group pluralist approach. The leading issue in the case is whether a for-profit corporate body can possess a recognized right to freedom of religion quite apart from the rights of its members and use this right to exempt itself from paying for contraceptives for employees as mandated by the Affordable Care Act. On Cohen's account, Hobby Lobby raises questions about whether religious groups can possess jurisdictional authority to make decisions over employees (including those who are not co-religionists). The case provides Cohen with a basis to argue that groupbased pluralism violates basic liberal and democratic values and to argue that sovereign authority is 'immanent' in the sense that it is based on the justness of authority, not 'meta-social' as the pluralist maintained.

Yet, as I see it, the democratic legitimacy of some form of group-based legal pluralism is not at issue in the case because no one (including Cohen) disagrees that some non-profit associations, such as churches, should be exempt from some kinds of public regulations. Rather one problem with the decision is that Hobby Lobby is a for-profit group. Whereas a pluralist might argue that a Church should be exempt from some public regulations that interfere with practicing its faith, Hobby Lobby is a business, which employs 13.000 people of diverse religious backgrounds, and whose leading purpose is to make a profit. On this basis alone, it is a mistake in my view (and Cohen's) to extend religious entitlements to it. A second problem is that Hobby Lobby aims to use religious freedom to withhold citizenship entitlements (i.e., state-mandated health care benefits) from all of its employees and thereby is proposing to interfere with a policy that can be reasonably construed to be amongst the most important individual entitlements secured by liberal democratic states today. On this reading, the ruling in the case arguably exposes one of the chief weaknesses of the group pluralist approach, namely, that pluralism offers a sometimes confused and impoverished view of the standing the state has as an association of citizens. ${ }^{9}$

8 Avigail Eisenberg, Reconstructing Political Pluralism (Albany NY: SUNY Press, 1995), 75-83.

9 Pluralist views of the state range from those which insist that the state is merely a referee amongst associations to those which hold that the state is an association in its own right with specific functions or purposes of its own. 
Some recent accounts of political pluralism attempt to remedy this deficiency in order to offer a more subtle and convincing pluralist theory. For example, Victor Muñiz-Fraticelli offers an analytically cogent approach to group-based pluralism with a (potentially) robust notion of the state as an association of citizenship. ${ }^{10}$ According to Muñiz-Fraticelli's account, the state plays two crucial roles in pluralism: first, it possesses authority to fulfil its own purposes as an association of citizens, and second, it provides an institutional context in which other associations, such as churches, can exercise their authority effectively. In this second respect, the state facilitates association by guaranteeing the individual's right to associate and the individual's right to submit to the authority of associations. In this way, the state facilitates the authority of associations in relation to their leading purposes.

One consequence of this approach is that jurisdictional conflicts will frequently occur amongst associations, between associations and the state, and even between the two roles of the state because matters related to the leading purposes of different associations are bound to overlap and conflict with each other, and sometimes it is difficult to know which association's authority appropriately prevails. For instance, states should not interfere in tenure decisions just as universities should not deny their members the right to unionize. Nor, as in the case at hand, should businesses (or churches) interfere in health care entitlements. Yet, one can easily imagine how these issues could raise concerns relevant to different associations. Because associations claim authority over similar and overlapping aspects of human conduct, disagreements between and amongst them about jurisdictional authority are bound to arise and ought to be considered part of democratic politics as well as consistent with liberal values and entitlements, especially freedom of association. ${ }^{11}$

So, from a pluralist perspective, the Court's recognition of Hobby Lobby's right to freedom of religion can be interpreted as a means to facilitate the purpose for which Hobby Lobby was incorporated, namely, for the owners to run a business based on their religious values. But as Cohen points out, the court should not extend religious rights to groups which incorporate for the purpose of profit. And what about the denial of health care benefits to employees? A group pluralist could argue that it is not up to the state to dictate the religious purposes of lawful associations but nor is it up to the court to ignore the legitimate purposes for which the state, as an association, exists. These purposes include ones associated with citizenship and today potentially include aims related to defence, immigration, keeping contracts, social welfare policy, and, in most states, the provision of health care. In other words, one problem with Hobby Lobby may be less a matter of strong group pluralism and more a matter of the court giving short shrift to the legitimate purposes of the state and specifically to the recognition of health care as a citizenship entitlement and a basic right. Whereas religious values can

10 Victor Muñiz-Fraticelli, The Structure of Pluralism: On the Authority of Associations (Oxford: Oxford University Press, 2014), 168-80.

11 Muñiz-Fraticelli, The Structure of Pluralism, 175-76. 
touch on every facet of human conduct, so can citizenship. And so, in this way, the case exhibits one of the key challenges for group-based pluralism today and one of the significant weaknesses of the early pluralist approaches.

\section{Group accommodation and the judicial assessment of religious practices}

Whereas group pluralism is motivated by the need to recognize the legitimate authority of different associations, including religious groups, the aim of group accommodation is to establish fair terms for the inclusion of minorities in public life. Understood in this way, debates about the accommodation of religious (or cultural) groups are usually related to multicultural politics. Now, Cohen's paper is not a critique of multiculturalism and, as she states, her concerns are not directed towards 'accommodations meant to protect the religious from majority injustice or insensitivity ${ }^{12}$ which is what multiculturalism aims to do. But the 'accommodation discourse' mentioned repeatedly in her paper is today usually understood as a discourse about accommodating cultural and religious diversity through equitable inclusion. What I refer to below as 'accommodation as inclusion' is also the leading approach taken to resolve cases about employment discrimination in most western states. So it is directly relevant to the cases Cohen analyzes, especially Hosanna-Tabor, which is a case about a church seeking an exemption from employment discrimination laws in order to avoid a lawsuit. For these reasons, it is worth considering how accommodation in this sense positions groups and group authority differently from the group pluralist approaches described above.

Perhaps, the most important difference between group pluralism and 'accommodation as inclusion' is that 'accommodation as inclusion' aims at including groups and integrating them into the public sphere rather than carving out a separate sphere of group-based authority. Accommodation, in this sense, is an approach to liberal citizenship which holds that the equal treatment of individuals sometimes requires the legal recognition of group-based differences, including differences based on gender, race, culture, sexuality, disability, religion amongst other categories, and requires balancing these interests with the interests of employers or the state. The impact of this approach can be traced perhaps no more clearly than in employment discrimination law where, since the mid-1970s in the US and mid-1980s in Canada, the leading standard for assessing and remedying discrimination against employees has been the standard of 'reasonable accommodation' whose principle idea is that treating individuals equally requires sensitivity to their differences including differences related to their religious identities.

Accommodation, as it is employed in these contexts, is an approach about equality, about minority inclusion in the public sphere, and thereby about issues that Cohen wishes to set aside in her paper. Yet, it overlaps with what Cohen calls 'accommodationism' in two respects. First, several criticisms Cohen levies against 
accommodationism are the same criticisms levied against 'accommodation as inclusion' in public debates today. These criticisms include the charge that accommodation goes too far because it offers minorities a legal means to take over the public sphere by forcing majorities to change rules about the workplace, public education, public holidays, etc., in the name of (a misconceived and illiberal) group-based equality. In other words, critics of accommodation as inclusion often use rhetoric about the 'minoritarian' or group-based nature of multicultural protections to draw attention to the illiberal, i.e., discriminatory and harmful, nature of some group practices and the insularity of some (often undemocratic) groups which, they argue, multiculturalism erroneously protects. So, at least at the level of public rhetoric, it is not uncommon to find critics confusing minority accommodation with group-based empowerment and arguing that multiculturalism is a group-based politics. Some of these criticisms appear to be similar to the concern expressed by Cohen that under the banner of 'freedom of religion' travel disturbing group-based challenges to liberal democratic values.

In my view, these concerns are exaggerated and distorting. They make it seem like an approach meant to include minorities is, in fact, a means to sanction the illiberal practices of some groups and group isolation from the public sphere. But the aim of 'accommodation as inclusion' is not to empower groups against the broader public sphere. In fact, one common criticisms of accommodation as it is legally applied is that sometimes it overprotects the status quo by shielding longstanding inequitable rules from being overturned when changing them could cause a majority or an employer hardship. ${ }^{13}$ The accommodation approach obliges the state (as well as employers, landlords, and potentially others) to accommodate minorities unless doing so is 'unreasonable'. Without getting into the legal details of the requirement (which vary amongst jurisdictions in any case), the general idea behind reasonable accommodation is that sometimes the public sphere is structured in ways that favour majority values or ways of life and thereby can expose minorities to unfair disadvantages and even disrespect. So, in order to be inclusive, the interests of majorities and minorities have to be balanced and, if possible, reconciled, which sometimes means assessing how to accommodate and include minorities in the public sphere in 'reasonable' ways, that is, in ways that will not cause 'undue hardship' or violate a 'compelling state interest'. For this reason, courts are mandated to examine the 'hardships' that employers claim they face or the compelling interests that states sometimes identify to justify laws that violate religious freedom.

13 Some critics have argued that reasonable accommodation is a superficial and conservative approach to inequality, which can lead to disappointing results where injustice towards a marginalized group runs deep and has shaped how businesses or public institutions operate. Where accommodation is expensive or requires a significant reorganization of the workplace, it could be viewed by a court as 'unreasonable' in the sense of causing 'undue hardship' by threatening the solvency of a business. For instance, historically, the requirement that workplaces must be wheelchair accessible required significant changes to physical infrastructure that necessitated state intervention and public funding. If left to employers alone, such accommodations would have probably been found to constitute undue hardship. See Shelagh Day and Gwen Brodsky, 'The duty to accommodate: who will benefit?' Canadian Bar Review 75 (1996). 
Hosanna-Tabor can be read as a case partly about accommodation in this sense rather than as a case exemplifying a trend towards jurisdictional accommodation in Cohen's sense. In the case, Hosanna-Tabor Evangelical Church and School sought exemption from employment discrimination rules which one of its employees (who the Church claims is a minister) wants to use to sue the Church. As the court recognizes, ministerial exception of one form or another has a longstanding history in western liberal democracies, all of which, to my knowledge, accommodate churches by allowing them to discriminate for religious reasons when choosing clergy. But in Hosanna-Tabor, the Court seems to broaden this exception, by allowing the Church to discriminate on the basis of disability (or possibly any basis) when it comes to choosing its clergy and so one contentious issue in this case is about how broad this accommodation should be. Whereas this issue is controversial, it is difficult to see it as a thin of a wedge that leads to group-based pluralism. In part, this is because accommodation requires balancing interests to determine which interest is more weighty rather than dividing interests into separate silos or spheres of associational jurisdiction, as group-based pluralism requires. To grant churches an exception to employment law in one rather specific domain, as the US Supreme Court does in Hosanna-Tabor, after the Court has assessed and weighed the Church's claim against the state's claim, seems to be a reasonable procedure. One might disagree about how the relevant interests were assessed and weighed by the Court, but the approach taken to resolving the matter is clearly different from one that simply recognizes the Church's immunity from judicial scrutiny or state law altogether. Partly for this reason, the group pluralism reading of the case can be resisted.

At the same time, this case reveals one of the challenges of deciding cases about religious accommodation fairly which is the extent to which judges and other state actors can legitimately question the authenticity of religious practices or rules of conduct. In most religious accommodation cases, the individual claimant or, sometimes, the religious group is recognized as the authority on religious matters, and judges often require that claimants only establish their sincerity of belief in order to establish that a practice is mandated by their religious faith. For instance, it may not be appropriate for a secular court to decide whether a believer has violated religious doctrine and, as the Chief Justice of the Canadian Supreme Court recently put it, when courts undertake the task of analyzing religious doctrine they tread in 'forbidden domains' ${ }^{14}$ That said, it is sometimes difficult for judges to make sense of what kinds of religious accommodations are suitable without assessing the meaning and importance of a disputed religious practice or belief. In order to understand, minimally, what is at stake for a claimant and therefore what kinds of accommodation measures might be minimally restrictive of religious freedom, judges sometimes interpret religion, for instance, by distinguishing trivial from more central and meaningful religious practices and rules. So, in many accommodation cases, the challenge for judges is, on the one hand, to ensure that religious claimants have discretion to define their religious 
practices and rules in ways that are meaningful to them, and, on the other hand, for the court to assess those practices in order to understand what is at stake for the claimant and what kinds of accommodation measures will be suitable and fair.

In this respect, a key question in Hosanna-Tabor is whether the Church's rules about who counts as a minister are authentic in the sense that they are not being strategically deployed to shield the Church from being sued by an employee who claims that the real reason for her dismissal is because of a medical condition. A large part of the Supreme Court judgment focuses on whether the employee is really a minister and, in this sense, Hosanna-Tabor displays the all too common challenge judges face in religious accommodation cases of how to assess religious practices or rules without interrogating religious dogma. But in this case, the matter is not so complex. The Supreme Court follows the lower court in assessing the rules of ordination followed by the Church. The Court recognizes, in the first place, that deciding who ministers a church's faith is crucial both to the internal governance of a church and to how the church's beliefs are personified. ${ }^{15}$ The Court then turns to the question of whether the employee, in this case, counts as a minister. The Church claims that she does count, but rather than accepting the Church's position on the matter, the Court examines the Church's ordination procedure, the way in which the employee presented herself as a minister of the Church, and considers whether the employee actually fulfilled what can be recognized as ministering functions. ${ }^{16}$ On the basis of this evidence, the Supreme Court's decision favours the Church. Its conclusion, in this respect, is different from that reached by a lower court, which favoured the employee. But the issue here is not whether the Supreme Court correctly assessed whether the employee was a real minister but rather whether its assessment signals a relinquishment of state sovereignty and a 'political theological conception of the corporate' as described by Cohen. Given the court's reasoning, it is difficult to see this decision as an example of group-based pluralism or 'corporate immunity involving privileges ${ }^{\prime 17}$ rather than a case of religious group accommodation.

\section{Conclusion}

On my account, the differences between group pluralism and group accommodation are stark. They point to different approaches to state authority and religious freedom and they raise different challenges for fair decision making about religious groups. I have pointed out some of these differences in the cases of Hobby Lobby and Hosanna-Tabor. According to Cohen, pluralists support a political theological conception of the corporate community and treat religious associations as unique and special because religion derives its authority from otherworldly sources. Neither the accounts of group pluralism nor the accounts of group

17 Cohen, 'Freedom of Religion Inc.', 205. 
accommodation offered here rely on recognizing the special status of religion in this sense. In fact, both can avoid the tricky question of whether religion is special. The problem with group pluralism, I argue, has more to do with the weak account of citizenship in most pluralist approaches rather than their reliance on the idea that religion is unique and special. As for group accommodation, indeed, the challenge is to limit state power at least so that, when judges are required to assess disputed religious practices, they avoid interrogating religious dogma in ways that second-guess (and thereby risk distorting and misinterpreting) the religious values and rules of the devout. But similar risks arise in cases about the practices of cultural minorities and especially Indigenous peoples. So again, religion does not especially embody these risks.

Finally, like Cohen, I think Hobby Lobby and Hosanna-Tabor are mistaken decisions in some respects. But these decisions neither represent a united approach to constitutionalism nor one framed by political theology and group personality. Instead, the decisions reveal two different approaches to religious freedom - group pluralism and group accommodationism - and highlight some of the weaknesses and challenges of each approach. The decisions also a display a failure of the court to distinguish properly between non-profit and for-profit, to defend citizenship entitlements, and to acknowledge that, under some circumstances, the state can and does limit the concept of 'clergy'. These failures provide a sufficient basis to worry about the approach taken by American courts today to freedom of religion but for reasons different than those offered by Cohen. 